7. Reprod. Fert. (1974) 39, 337-347

\title{
PHOTOPERIODIC CONTROL OF TESTIS ACTIVITY IN THE VOLE, MICROTUS AGRESTIS
}

\author{
C. ANNE GROCOCK* AND J. R. CLARKE \\ Department of Agricultural Science, University of Oxford, Parks Road, Oxford OX1 3PF
}

(Received 24th October 1973)

\begin{abstract}
Summary. In voles, growth of testes and the onset and maintenance of their spermatogenic and endocrine activity are influenced by light. From experiments employing several different photoperiods recurring every $12,24,36$ or $48 \mathrm{hr}$, it seems that the effect of a photoperiod depends on the time of its occurrence during the day. Voles appear to have an endogenous circadian rhythm of photosensitivity. It is suggested that testes mature more rapidly or are maintained in a more active state if the external light stimulus coincides with the postulated endogenous photosensitive period.
\end{abstract}

\section{INTRODUCTION}

Under natural conditions the vole (Microtus agrestis) breeds in the spring and summer but not in the autumn and winter. This seasonal change was attributed by Baker \& Ranson (1933) to the influence of hours of sunshine, and in the laboratory it has been shown that photoperiod affects the growth of gonads and maintenance of their activity (Baker \& Ranson, 1932; Clarke \& Kennedy, 1967; Breed \& Clarke, 1970). Testes of voles living in $6 \mathrm{hr}$ light/day are smaller and less active than those from animals given 15 or $16 \mathrm{hr}$ light daily. Essentially similar effects of photoperiod have been observed in Microtus arvalis (Martinet, 1963).

In the hope of gaining insight into the underlying processes by which altered photoperiod is perceived, experiments have been carried out to discover which part of the light/dark cycle causes changes in gonadal activity.

\section{MATERIALS AND METHODS}

All animals were derived from the closed colony which has been maintained in this laboratory since 1959. They had lived from birth until the start of experiments in a photoperiod of $16 \mathrm{hr}$ per $24 \mathrm{hr}$ (16L:8D). Mature males were $84 \pm 3$ and juveniles $18 \pm 0.3$ days old at the beginning of experiments. Mature males were kept one to a cage to prevent fighting, but juveniles were caged in groups of four. Males allowed to mature in a group rarely fight, but intense fighting often occurs if mature males from different groups are brought together. Animals were kept in wire mesh cages with solid floors on sawdust litter.

* Present address: Department of Human Anatomy, University Museum, Oxford. 
Cotton wool and hay were provided as nesting material. Animals were fed on whole oats, carrots, and Oxoid rat and mouse breeding diet. Water was permanently available.

Experiments were of a randomized block design (Bailey, 1959).

Animals in each experiment were allocated to blocks within which they were matched for age, body weight and sexual development, and were allotted at random to the treatments, details of which are given in the 'Results'. Cages were put into light-proof cupboards internally illuminated by two $25 \mathrm{~W}$ bulbs connected to time switches. The times at which lights switched on and off were dictated largely by considerations of convenience in the servicing of cages, but the first daily onset of a photoperiod was usually at about the time lights switched on in the breeding colony ( 08.00 hours). The light intensity at cages was approximately equal to that in grassland runways of voles in the field (Glarke \& Kennedy, 1967). Treatments continued for 8 weeks. Animals were then killed with coal gas or ether. None of the experimental treatments had any significant effect on body weight. Final body weights ranged from 26 to $34 \mathrm{~g}$ in experiments involving initially prepubertal animals, and 33 to $43 \mathrm{~g}$ in those with initially sexually mature voles. Testes were weighed and fixed in Bouin's fluid, in which bodies were also stored. The fixed seminal vesicles were weighed to provide a measure of androgen release. Data were analysed by analysis of variance, and by $t$ test for differences between means (Bailey, 1959).

Testes were embedded in paraffin wax, sectioned at $5 \mu \mathrm{m}$, stained with Ehrlich's haematoxylin and eosin, and classified for functional state using a spermatogenic and an interstitial cell index. The spermatogenic index (values from 5 to 0 ) gives a measure of seminiferous epithelium activity, 5 representing complete spermatogenesis with abundant sperm production and 0 the presence only of Sertoli cells and spermatogonia. The interstitial cell index (5 to 1$)$ is an

\section{EXPLANATION OF PLATE 1}

Sections of the testis of voles to illustrate the spermatogenic and interstitial cell index. The sections, stained with haematoxylin and eosin, are all at the same magnification: the scale line in Fig. 2 is $50 \mu \mathrm{m}$. There is a progressive reduction from Fig. 1 to Fig. 6 in the diameter of the seminiferous tubules, number of germ cells, size of interstitial cell patches and shape of interstitial cell nuclei. Abbreviations: ic, interstitial cells; spz, spermatozoa; spde, elongate spermatids; spdr, round spermatid; spc, primary spermatocyte; spg, spermatogonium; s, Sertoli cell.

Fig. 1. Spermatogenic index 5 , interstitial cell index 5 . The seminiferous tubules are large and spermatogenesis is complete. The interstitial cell patches are very large and the cell nuclei are round.

FIG. 2. Spermatogenic index 4, interstitial cell index 4. Spermatogenesis is complete but elongated spermatids and spermatozoa are less abundant. The interstitial cell patches are slightly smaller.

FIG. 3. Spermatogenic index 3, interstitial cell index 3. There is further reduction in the number of spermatozoa and spermatids. The interstitial cell patches are much smaller but the nuclei are still round.

Fig. 4. Spermatogenic index 2, interstitial cell index 2. No elongated spermatids are present but round spermatids still occur. Some interstitial cell nuclei are no longer round.

FIG. 5. Spermatogenic index 1, interstitial cell index 1. There are small tubules containing only Sertoli cells, spermatogonia and primary spermatocytes. The interstitial cell patches are very small and most of the cell nuclei are no longer round.

FIg. 6. Spermatogenic index 0 , interstitial cell index 1 . The tubules are very small and contain only Sertoli cells and spermatogonia; a few spermatocytes are visible. The interstitial cell patches are like those in Fig. 5. 


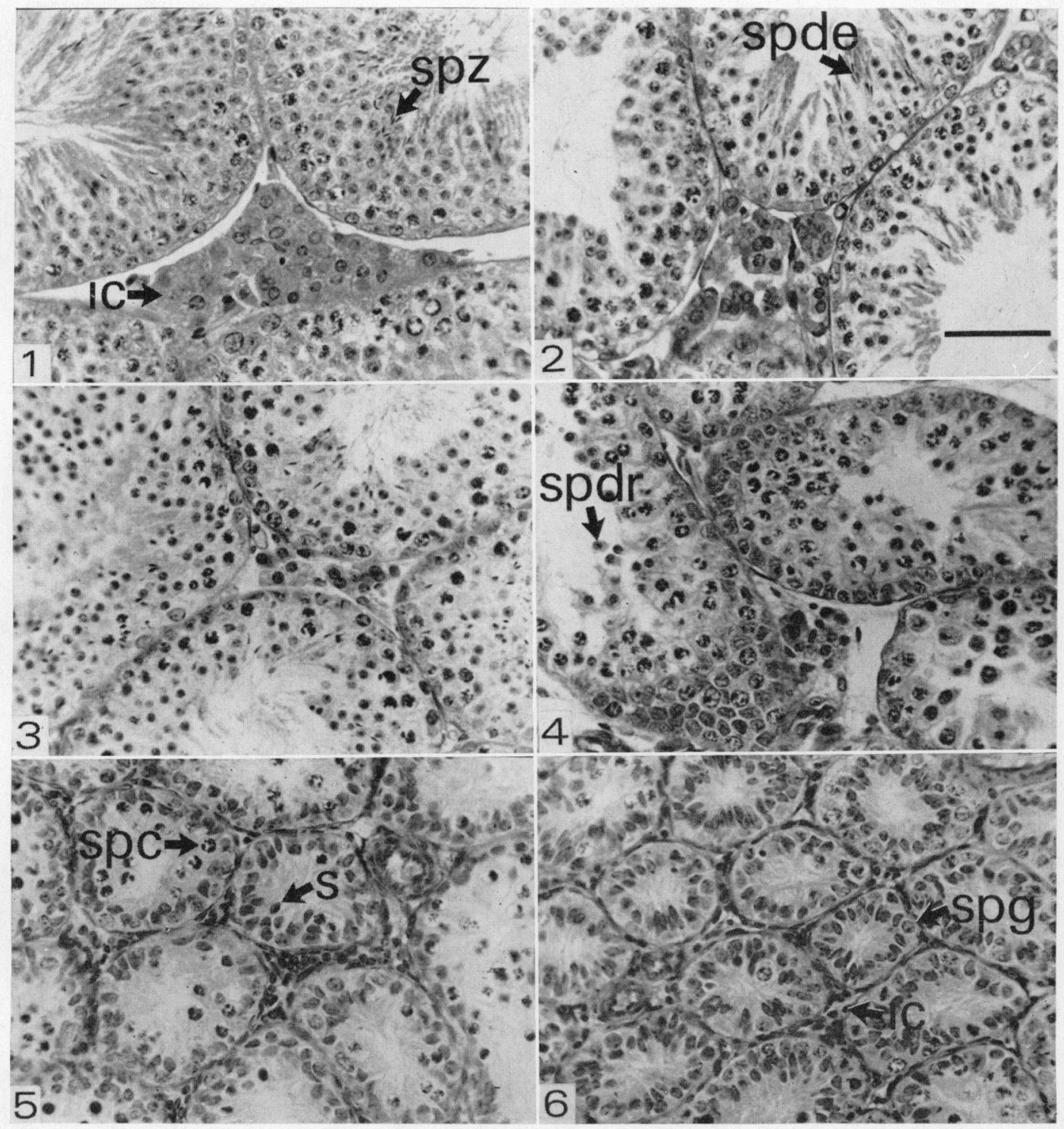

(fiacing p. 338) 
assessment of the state of interstitial tissue, 5 being maximum and 1 minimum development. It is based on the change in size of interstitial patches, and their component cells, and on the altered shape (from round to elongate) of nuclei (Pl. 1, Figs 1 to 6$)$.

\section{Experiment 1}

\section{RESULTS}

A light regimen of $6 \mathrm{~L}: 18 \mathrm{D}$ causes regression or inhibition of testes (Clarke \& Kennedy, 1967). Should the ratio of L:D be important, then 3L:9D:3L:9D would also cause regression or inhibition possibly more quickly than $6 \mathrm{~L}: 18 \mathrm{D}$. If the absolute amount of light and dark is important, regression or inhibition of testes would take place at the same rate in these two different light regimens.

Twelve sexually mature males were distributed equally between three treatments: $\mathrm{T}_{0}$ (killed at the beginning of the experiment); $6 \mathrm{~L}: 18 \mathrm{D}$ (lights on 09.00 to 15.00 hours); $3 \mathrm{~L}: 9 \mathrm{D}: 3 \mathrm{~L}: 9 \mathrm{D}$ (lights on 09.00 to 12.00 hours; 21.00 to 24.00 hours). Testis and seminal vesicle weights are given in Table 1 . Analysis of variance revealed a significant effect of treatments on testis $(P<0.01)$, but not on seminal vesicle $(0 \cdot 1>P>0.05)$ weights. Neither in this experiment nor

Table 1. Effect of a constant ratio of hours of light (L) and dark (D) upon testis and seminal vesicle weights and testis histology of mature voles

\begin{tabular}{l|c|c|c|c}
\hline \multicolumn{1}{c|}{ Treatment * } & $\begin{array}{c}\text { Wt of } \\
\text { testes } \\
(m g \pm S . E .)\end{array}$ & $\begin{array}{c}\text { Wt of } \\
\text { seminal vesicles } \\
(m g \pm S . E .)\end{array}$ & $\begin{array}{c}\text { Spermatogenic } \\
\text { index } \dagger\end{array}$ & $\begin{array}{c}\text { Interstitial } \\
\text { cell index } \dagger\end{array}$ \\
\hline $\mathrm{T}_{0} \ddagger$ & $340 \cdot 5 \pm 22 \cdot 3$ & $66 \cdot 3 \pm 15 \cdot 6$ & $5 \cdot 0 \pm 0$ & $5 \cdot 0 \pm 0$ \\
$6 \mathrm{~L}: 18 \mathrm{D}$ & $187 \cdot 5 \pm 38 \cdot 6$ & $123 \cdot 0 \pm 40 \cdot 5$ & $3 \cdot 2 \pm 0 \cdot 8$ & $4 \cdot 0 \pm 0 \cdot 4$ \\
$3 \mathrm{~L}: 9 \mathrm{D}: 3 \mathrm{~L}: 9 \mathrm{D}$ & $407 \cdot 5 \pm 46 \cdot 3$ & $177 \cdot 5 \pm 15 \cdot 0$ & $5 \cdot 0 \pm 0$ & $4 \cdot 5 \pm 0 \cdot 3$ \\
\hline
\end{tabular}

* Continued for 8 weeks, four animals per group.

+ See text for details.

† Animals killed at start of experiment.

in any later one was there a significant block effect. The testes of males in the $\mathrm{T}_{0}$ and $3 \mathrm{~L}: 9 \mathrm{D}: 3 \mathrm{~L}: 9 \mathrm{D}$ treatments, while not differing significantly from each other, were significantly larger than those from $6 \mathrm{~L}: 18 \mathrm{D}(P<0.01$ and $<0.002$ respectively). There was a significant difference between the weights of seminal vesicles from $\mathrm{T}_{0}$ and $3 \mathrm{~L}: 9 \mathrm{D}: 3 \mathrm{~L}: 9 \mathrm{D}$ males $(P<0.05)$ but other seminal vesicle weight differences were not significant $(0 \cdot 1>P>0.05)$. That $T_{0}$ seminal vesicles were the smallest no doubt reflects the age difference between these $(84 \pm 3$ days old) and the other animals (8 weeks older). Other work has shown that during normal development in a 16L:8D regimen, seminal vesicles change from 60 to $165 \mathrm{mg}$ between the ages of 56 and 112 days (J. R. Clarke, unpublished observations). Compared with $\mathrm{T}_{0}$ and $3 \mathrm{~L}: 9 \mathrm{D}: 3 \mathrm{~L}: 9 \mathrm{D}$ males, spermatogenic activity was appreciably lower in $6 \mathrm{~L}: 18 \mathrm{D}$ males in which there was also some reduction in size of interstitial cell patches (Table 1 ).

\section{Experiment 2}

It was totally unexpected that the $3 \mathrm{~L}: 9 \mathrm{D}: 3 \mathrm{~L}: 9 \mathrm{D}$ treatment should allow 
maintenance of full testicular activity, unlike the $6 \mathrm{~L}: 18 \mathrm{D}$ which caused some testicular regression. There appeared to be two possible interpretations of these results: (1) the length of each discrete dark period might determine whether a particular lighting regimen is stimulatory; (2) independent of the lengths of the dark periods, the occurrence of two light periods in $24 \mathrm{hr}$ might in itself be stimulatory.

To investigate which of these possibilities might be correct, the effect of 3L:2D:3L:16D was compared with that of $3 \mathrm{~L}: 9 \mathrm{D}: 3 \mathrm{~L}: 9 \mathrm{D}$ and of $15 \mathrm{~L}: 9 \mathrm{D}$. The 3L:2D:3L:16D schedule contains in every $24 \mathrm{hr}$ two light periods separated by a short and a long dark period. If the repetition of the light periods is the stimulatory factor, then animals experiencing this treatment ought to have large, active testes. If the length of dark periods is important, males in such lighting schedules should have less active, regressed (or inhibited) testes. Twenty-four sexually mature males were distributed equally between three treatments: $15 \mathrm{~L}: 9 \mathrm{D}$ (lights on 09.00 to 24.00 hours); 3L:9D: 3L:9D (lights on 09.00 to 12.00 hours and 21.00 to 24.00 hours); $3 \mathrm{~L}: 2 \mathrm{D}: 3 \mathrm{~L}: 16 \mathrm{D}$ lights on 09.00 to 12.00 hours and 14.00 to 17.00 hours). Testis and seminal vesicle weights are given in Table 2. Analysis of variance showed a significant effect of

Table 2. Effect of the length of the dark period upon testis and seminal vesicle weights and testis histology of mature voles

\begin{tabular}{l|c|c|c|c}
\hline \multicolumn{1}{|c|}{ Treatment * } & $\begin{array}{c}\text { Wt of } \\
\text { testes } \\
(m g \pm S . E .)\end{array}$ & $\begin{array}{c}\text { Wt of } \\
\text { seminal vesicles } \\
(m g \pm S . E .)\end{array}$ & $\begin{array}{c}\text { Spermatogenic } \\
\text { index } \dagger\end{array}$ & $\begin{array}{c}\text { Interstitial } \\
\text { cell index } \dagger\end{array}$ \\
\hline 15L:9D & $323 \cdot 5 \pm 36 \cdot 2$ & $162 \cdot 6 \pm 17 \cdot 7$ & $4 \cdot 5 \pm 0 \cdot 5$ & $4 \cdot 9 \pm 0 \cdot 1$ \\
3L:9D:3L:9D & $383 \cdot 9 \pm 24 \cdot 0$ & $20 \cdot 6 \pm 13 \cdot 4$ & $5 \cdot 0 \pm 0$ & $4 \cdot 7 \pm 0.2$ \\
3L:2D:3L:16D & $217 \cdot 2 \pm 35 \cdot 2$ & $101 \cdot 2 \pm 18 \cdot 4$ & $3 \cdot 7 \pm 0 \cdot 6$ & $3 \cdot 6 \pm 0.4$ \\
\hline
\end{tabular}

* Gontinued for 8 weeks, eight animals per group.

$\dagger$ See text for details

treatments upon testes and seminal vesicles $(P<0 \cdot 01)$. Means for both organs were significantly smaller in $3 \mathrm{~L}: 2 \mathrm{D}: 3 \mathrm{~L}: 16 \mathrm{D}$ males than in $15 \mathrm{~L}: 9 \mathrm{D}$ males $(P<0.05$ for testes; $P<0.01$ for seminal vesicles) or in $3 \mathrm{~L}: 9 \mathrm{D}: 3 \mathrm{~L}: 9 \mathrm{D}$ males $(P<0.002$ for testes; $P<0.001$ for seminal vesicles). Mean seminal vesicle weight was significantly larger in $3 \mathrm{~L}: 9 \mathrm{D}: 3 \mathrm{~L}: 9 \mathrm{D}$ males than in $15 \mathrm{~L}: 9 \mathrm{D}$ males $(P<0.05)$. Spermatozoa were being produced in larger numbers and patches of interstitial cells were larger in $15 \mathrm{~L}: 9 \mathrm{D}$ and $3 \mathrm{~L}: 9 \mathrm{D}: 3 \mathrm{~L}: 9 \mathrm{D}$ males than in 3L:2D:3L:16D males (Table 2). Testes in 3L:2D:3L:16D males ranged from some which were fully mature to others in which tubules contained primary spermatocytes as the most advanced stage in spermatogenesis and interstitial cells were small with elongate nuclei. The histological results indicated that testes in $3 \mathrm{~L}: 2 \mathrm{D}: 3 \mathrm{~L}: 16 \mathrm{D}$ males had regressed to some extent.

\section{Experiment 3}

The preceding experiments involved a study of the effect of photoperiods upon already fully developed testes. An investigation was therefore made of the influence of these light regimens upon the testes of initially juvenile animals. 
Sixty-four juvenile males were distributed equally between four treatments: 15L:9D; 3L:9D:3L:9D; 6L:18D; 3L:2D:3L:16D. Lights were on at the same times as in the first two experiments. Testis and seminal vesicle weights are given in Table 3. Analysis of variance showed a significant effect of treatments $(P<0.01)$ upon testis and seminal vesicle weights. Means for both organs from the 15L:9D and $3 \mathrm{~L}: 9 \mathrm{D}: 3 \mathrm{~L}: 9 \mathrm{D}$ males, though not differing from each other, were significantly larger than in $6 \mathrm{~L}: 18 \mathrm{D}$ or $3 \mathrm{~L}: 2 \mathrm{D}: 3 \mathrm{~L}: 16 \mathrm{D}$ males $(P<0.001$ in all cases except for seminal vesicles of $15 \mathrm{~L}: 9 \mathrm{D}$ and $3 \mathrm{~L}: 2 \mathrm{D}: 3 \mathrm{~L}: 16 \mathrm{D}$ males for which $P<0.01$ ). Means for each organ in 6L:18D and 3L:2D:3L:16D males did not differ significantly from each other. In general, testes in 15L:9D and $3 \mathrm{~L}: 9 \mathrm{D}: 3 \mathrm{~L}: 9 \mathrm{D}$ males were fully mature, while those from $6 \mathrm{~L}: 18 \mathrm{D}$ and 3L:2D:3L:16D males showed less spermatogenic activity and poorer development of interstitial cells (Table 3).

Table 3. Testis and seminal vesicle weights and testis histology of initially juvenile voles subjected to different light regimens

\begin{tabular}{|c|c|c|c|c|c|}
\hline Treatment* & $\begin{array}{l}\text { No. of } \\
\text { animals }\end{array}$ & $\begin{array}{c}\text { Wt of } \\
\text { testes } \\
(m g \pm S . E .)\end{array}$ & $\begin{array}{c}\text { Wt of } \\
\text { seminal vesicles } \\
(m g \pm S . E .)\end{array}$ & $\begin{array}{l}\text { Spermatogenic } \\
\text { index } \dagger\end{array}$ & $\begin{array}{l}\text { Interstitial } \\
\text { cell index } \dagger\end{array}$ \\
\hline $\begin{array}{l}\text { Experiment } 3 \\
\text { 15L:9D } \\
\text { 3L:9D:3L:9D } \\
\text { 6L:18D } \\
\text { 3L:2D:3L:16D }\end{array}$ & $\begin{array}{l}13 \\
16 \\
16 \\
15\end{array}$ & $\begin{array}{l}304 \cdot 3 \pm 28 \cdot 5 \\
334 \cdot 2 \pm 20 \cdot 2 \\
133 \cdot 1 \pm 20 \cdot 9 \\
128 \cdot 6 \pm 18 \cdot 0\end{array}$ & $\begin{array}{l}76 \cdot 0 \pm 12 \cdot 7 \\
92 \cdot 2 \pm 11 \cdot 7 \\
19 \cdot 1 \pm 4 \cdot 9 \\
27 \cdot 3 \pm 8 \cdot 6\end{array}$ & $\begin{array}{l}4 \cdot 3 \pm 0 \cdot 3 \\
4 \cdot 9 \pm 0 \cdot 1 \\
3 \cdot 0 \pm 0 \cdot 3 \\
3 \cdot 3 \pm 0 \cdot 3\end{array}$ & $\begin{array}{l}4 \cdot 4 \pm 0.2 \\
4 \cdot 7 \pm 0 \cdot 1 \\
3 \cdot 2 \pm 0.3 \\
3 \cdot 7 \pm 0.2\end{array}$ \\
\hline $\begin{array}{c}\text { Experiment } 4 \\
18 \mathrm{~L}: 6 \mathrm{D} \\
6 \mathrm{~L}: 30 \mathrm{D} \\
6 \mathrm{~L}: 18 \mathrm{D} \\
6 \mathrm{~L}: 42 \mathrm{D}(1) \\
6 \mathrm{~L}: 42 \mathrm{D}(2)\end{array}$ & $\begin{array}{l}27 \\
14 \\
24 \\
10 \\
12\end{array}$ & $\begin{array}{l}491 \cdot 6 \pm 19 \cdot 5 \\
375.9 \pm 48 \cdot 9 \\
139 \cdot 7 \pm 18 \cdot 4 \\
169 \cdot 0 \pm 34 \cdot 0 \\
100 \cdot 3 \pm 21 \cdot 6\end{array}$ & $\begin{array}{r}149 \cdot 5 \pm 10 \cdot 7 \\
110 \cdot 5 \pm 17 \cdot 3 \\
29 \cdot 1 \pm 6 \cdot 6 \\
37 \cdot 4 \pm 10 \cdot 3 \\
19 \cdot 6 \pm 8 \cdot 0\end{array}$ & $\begin{array}{l}4 \cdot 9 \pm 0 \cdot 1 \\
4 \cdot 4 \pm 0 \cdot 3 \\
3 \cdot 1 \pm 0 \cdot 3 \\
3 \cdot 4 \pm 0 \cdot 4 \\
2 \cdot 6 \pm 0 \cdot 3\end{array}$ & $\begin{array}{l}4 \cdot 9 \pm 0 \cdot 1 \\
4 \cdot 6 \pm 0 \cdot 2 \\
3 \cdot 2 \pm 0 \cdot 2 \\
3 \cdot 2 \pm 0 \cdot 4 \\
2 \cdot 7 \pm 0 \cdot 2\end{array}$ \\
\hline
\end{tabular}

Inequalities in the number of animals were due to accidental deaths during the course of the treatments and to the pooling of two sets of results for each of the 18L:6D and 6L:18D treatments in Exp. 4.

* Continued for 8 weeks.

+ See text for details.

\section{Experiment 4}

The above experiments suggest that the length of the dark period, or its position in the day, is important for the control of testis activity. The absolute length of the light period (within the limits employed here), or its simple repetition, appear not to be significant. There are two possible explanations for the effects so far observed.

(1) For a light regimen to inhibit or cause regression of testes, a period of darkness must be $12 \mathrm{hr}$ or more long (see Martinet, 1963; Breed \& Clarke, 1970). This might be the time required either to produce a substance which directly or indirectly stops gonadal activity, or to eliminate a gonadal activator made during the photoperiod.

(2) There is an endogenous circadian rhythm of sensitivity to a light stimulus, synchronization of the lighting with this endogenous rhythm being necessary for full testicular activity. This is essentially the system proposed by Bünning 
(1936, 1963) and elaborated by Pittendrigh \& Minis (1964) to explain daylength measurement in a variety of plants and animals. Each of these mechanisms could be envisaged as operating in the central nervous system, final pathways being from the hypothalamus to the adenohypophysis and gonads by the generally accepted endocrine controlling systems.

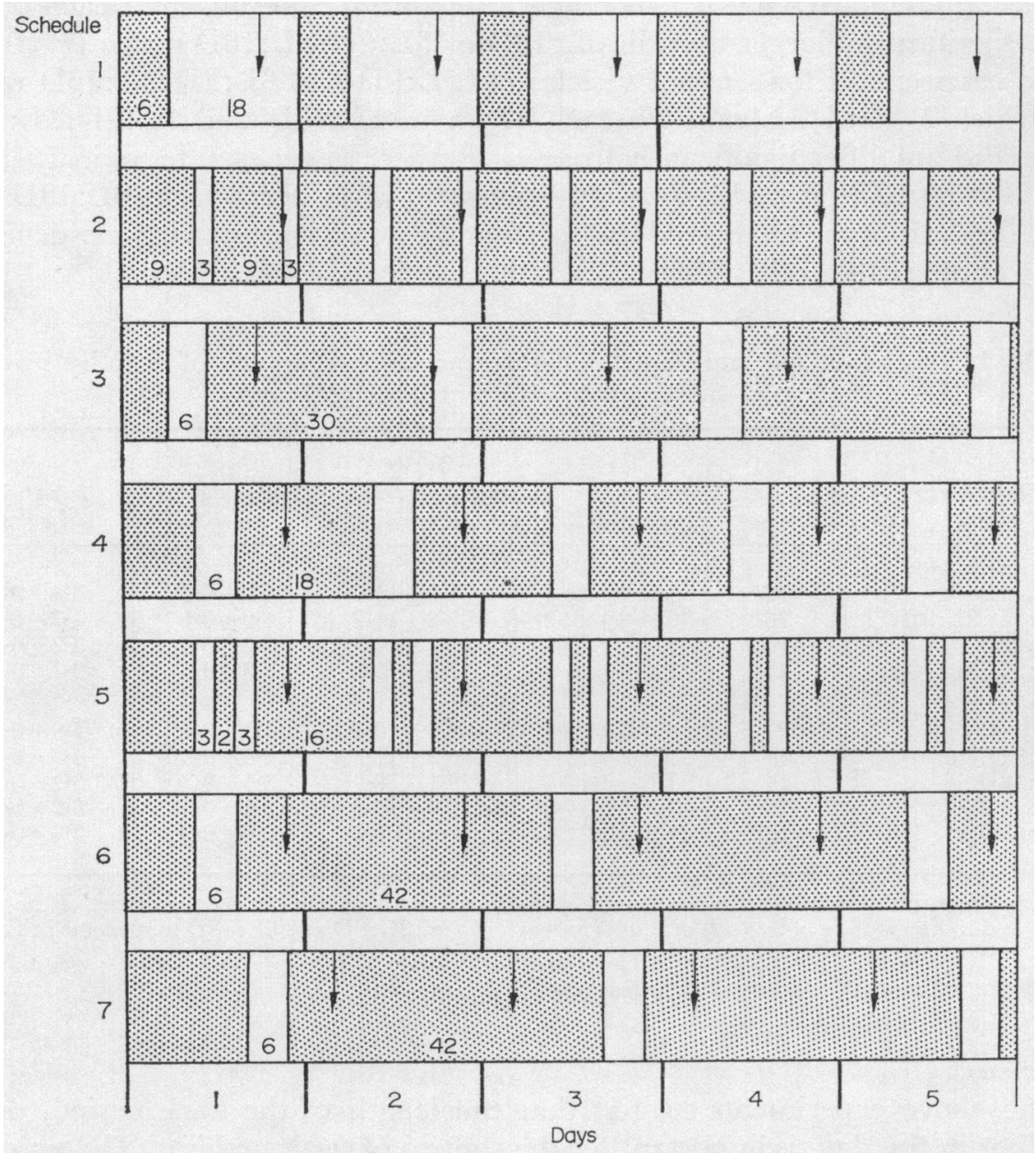

Text-Fig. 1. Representation of seven different experimental lighting schedules over 5 days. Light periods are indicated by open blocks, and dark periods by shaded blocks. The figures on the blocks indicate the duration of the period in hr. Vertical arrows indicate the approximate time of onset of the postulated photosensitive period assuming that its position is determined by, and occurs $12 \mathrm{hr}$ after, the time of the experimental dawn. Small advances or delays in the phase of the endogenous photosensitive rhythm which may occur in Schedule 3 as a consequence of alternating dawns, and in Schedules 2 and 5 in which there are two dawns daily, have not been depicted. Schedules 1,2 and 3 permit greater testicular activity than Schedules $4,5,6$ and 7 .

Subjecting voles to $6 \mathrm{~L}: 30 \mathrm{D}$ should reveal which of these two explanations holds. If the first explanation is correct, this lighting would be an inhibitory or regressive regimen since the dark period exceeds $12 \mathrm{hr}$. To explain the second possibility, some further elaboration of possible mechanisms is necessary. In 
view of the postulated characteristics of circadian endogenous rhythms involved in daylength measurement in other organisms (Bünning, 1936, 1963; Pittendrigh $\&$ Minis, 1964), the vole may be supposed to have a single daily photosensitive period occurring $12 \mathrm{hr}$ after dawn. This rhythm of photosensitivity may be: (a) readily entrainable to a regular external light stimulus or (b) not readily entrainable, its phase being fixed by the time of 'dawn' early in life $(08.00$ hours for this colony). Thus (a) might allow development or maintenance of full testis activity in 6L:30D voles since the light stimulus and the photosensitive period would coincide at least once every 3 days (see below for further discussion of this), but a $6 \mathrm{~L}: 42 \mathrm{D}$ regimen would not arouse or maintain testicular activity since the photosensitive period would occur in darkness (Text-fig. 1, compare Schedule 3 with Schedules 6 and 7). If (b) were correct, a regimen of 6L:42D in which the photoperiod occurred in the evening (Text-fig. 1, Schedule 7) would be at least as stimulatory as $6 \mathrm{~L}: 30 \mathrm{D}$ and more effective than 6L:42D in which the photoperiod occurred earlier in the day (Schedule 6).

These ideas were tested in two separate experiments which together involved eighty-seven juvenile voles distributed between the following treatments: $18 \mathrm{~L}: 6 \mathrm{D}$ (lights on 06.00 to 24.00 hours); $6 \mathrm{~L}: 30 \mathrm{D}$ (in repeated cycles of 3 days, lights on 05.00 to 11.00 hours, Day 1, 17.00 to 23.00 hours, Day 2; and continuous darkness Day 3); 6L: 18D (lights on 09.00 to 15.00 hours); 6L:42D (1) (lights on 09.00 to 15.00 hours); $6 \mathrm{~L}: 42 \mathrm{D}$ (2) (lights on 16.00 to 22.00 hours). The 18L:6D and 6L:18D regimens were included in both experiments. Since the effects of these treatments upon testes and seminal vesicles did not differ in the two experiments, the results have been combined and all the results are given in Table 3. Analysis of variance showed a significant effect of treatments on testis and seminal vesicle weights $(P<0.001)$. Testes and seminal vesicles from 18L:6D males were significantly larger than those from $6 \mathrm{~L}: 30 \mathrm{D}$ males $(P<0.01$ for testes, $P<0.02$ for seminal vesicles) and from males on any of the other treatments $(P<0 \cdot 001)$. Testes and seminal vesicles from $6 \mathrm{~L}: 30 \mathrm{D}$ males were also significantly larger than those from $6 \mathrm{~L}: 18 \mathrm{D}, 6 \mathrm{~L}: 42 \mathrm{D}(1)$ and $6 \mathrm{~L}: 42 \mathrm{D}(2)$ males $(P<0 \cdot 001)$. The differences in organ weights of males on the last three treatments were not statistically significant. Testes from $18 \mathrm{~L}: 6 \mathrm{D}$ and $6 \mathrm{~L}: 30 \mathrm{D}$ males were more active spermatogenically and had higher interstitial cell indices than those from $6 \mathrm{~L}: 18 \mathrm{D}$ males or from those on either of the $6 \mathrm{~L}: 42 \mathrm{D}$ regimens (Table 3 ).

\section{DISCUSSION}

Testis and seminal vesicle weights and testis histology suggest that neither the length of light or dark periods, nor the ratio of light to dark, is important in determining the spermatogenic and endocrine activity of vole testes. Thus, $6 \mathrm{hr}$ light $/ 24 \mathrm{hr}$ in two equally spaced doses of $3 \mathrm{hr}$ each, or $6 \mathrm{hr}$ light $/ 36 \mathrm{hr}$, repeated for 8 weeks, allows testes to remain or to become fully functional. They resemble testes from animals maintained on long ('summer') photoperiods of 15 or $18 \mathrm{hr}$ light $/ 24 \mathrm{hr}$. But $6 \mathrm{hr}$ continuous light every 24 or $48 \mathrm{hr}$, or in two periods of $3 \mathrm{hr}$ separated by 2 and $16 \mathrm{hr}$ of darkness, does not permit full testicular activity or development. 
It appears therefore that the position of the light stimulus in each 24-hr period is one factor which determines whether or not a photoperiod is stimulatory for vole testes. In this regard, voles resemble the house finch, Carpodacus mexicanus (Hamner, 1963), the house sparrow, Passer domesticus (Menaker, 1965), the Japanese quail, Coturnix coturnix japonicus (Follett \& Sharp, 1969) and the golden hamster, Mesocricetus auratus (Elliott, Stetson \& Menaker, 1972). As with the above birds and the hamster, the results of the present experiments suggest the existence of an endogenous circadian rhythm of sensitivity to light whose phase can be altered by a sustained change in the time of photoperiods. The characteristics of this postulated endogenous rhythm of photosensitivity, i.e. the ease with which its phase can be shifted or the duration of the photosensitive period, are conjectural. Basing discussion on the supposed properties of the endogenous circadian rhythm underlying locomotor activity in some mammals and birds (Decoursey, 1961, 1964; Decoursey \& Decoursey, 1964; Menaker, 1965; Hamner \& Enright, 1967; Elliott et al., 1972), the physiological events in these experiments may have been as follows (see Text-fig. 1). Before the beginning of the treatments voles were subjected to a $16 \mathrm{~L}: 8 \mathrm{D}$ regimen in the animal room, with dawn at 08.00 hours. It has been suggested (p. 343 above) that the period of photosensitivity would commence about $12 \mathrm{hr}$ later, that is at 20.00 hours. In this pre-experimental period the phase of the endogenous rhythm would become established, though it would be alterable should dawn occur regularly at some other time. The experimental treatments involving simple light regimens (Schedules 1, 4 and 6 in Text-fig. 1), in which there is each day or every second day a single dawn at about the same time as in the pretreatment period, present no problem in interpretation. The photosensitive period would recur daily $12 \mathrm{hr}$ after dawn during illumination or darkness. Re-setting of the phase for circadian locomotor rhythms following alteration in the light regimen is gradual. There are small shifts of 1 to $2 \mathrm{hr}$ each day, and adjustment to the altered photoperiod takes a number of days (see references above). For voles in the $3 \mathrm{~L}: 9 \mathrm{D}: 3 \mathrm{~L}: 9 \mathrm{D}$ and $3 \mathrm{~L}: 2 \mathrm{D}: 3 \mathrm{~L}: 16 \mathrm{D}$ regimens (Schedules 2 and 5, Text-fig. 1), dawn could be regarded as occurring twice daily. On Day 1 of the 3L:9D:3L:9D regimen, dawn at 09.00 hours would cause the photosensitive period to commence at about 21.00 hours when the second dawn occurred. The latter might cause a slight advance in phase of the endogenous photosensitive rhythm on Day 2 (move to the left in Text-fig. 1), but this phase shift would be insufficient to cause the photosensitive period on Day 2 to coincide with that day's first light interval. Dawn at 09.00 hours on Day 2 would correct any such small phase shift so that the photosensitive period on that and subsequent days would occur (as on Day 1) at the start of the second daily light interval. For voles in the 3L:2D:3L:16D regimen, slight phase delay might be caused by the second daily light stimulus (move to the right in Text-fig. 1), but the photosensitive period would still commence in darkness. With the $6 \mathrm{~L}: 42 \mathrm{D}(2)$ regimen (Schedule 7, Text-fig. 1), dawn at 16.00 hours would cause a gradual phase shift of the pretreatment rhythm, so that by 5 to 10 days and therafter the photosensitive period would have its onset at 04.00 hours (during darkness). In the $6 \mathrm{~L}: 30 \mathrm{D}$ regimen (Schedule 3, Text-fig. 1), dawn at $36-\mathrm{hr}$ intervals occurs alternately at 05.00 and 17.00 hours. Dawn on 
Day 1 at 05.00 hours would advance the phase of the pretreatment rhythm by $3 \mathrm{hr}$, the photosensitive period now having its onset at 17.00 hours. The change in phase would be maintained on Day 2 and the onset of the photosensitive period would coincide with the start of the 6-hr light interval at 17.00 hours. This dawn on Day 2 would cause some phase shift, although the onset of the photosensitive period on Day 3 would presumably be advanced no more than $3 \mathrm{hr}$ (to be consistent with the shift on Day 1 and reports in the literature on alteration of phase of locomotor rhythms). On Day 4, dawn at 05.00 hours would cause the photosensitive period to commence again at 17.00 hours and, on Day 5, illumination and the photosensitive period would again coincide. In this way neuroendocrine changes, leading ultimately to gonadal activation, would be (temporarily) initiated every 3 days. Even were the advance in phase caused by successive dawns at 05.00 hours to occur by smaller steps, the onset of the photosensitive period would be (on Days 2, 5, etc.) within the 6-hr light interval. This system of daylength measurement, involving interaction of a light stimulus with an endogenous circadian rhythm in which a photosensitive period occurs about $12 \mathrm{hr}$ after dawn, would confine vole breeding (were daylength its only determinant: see below) to the period between the vernal and autumnal equinoxes.

Some of the properties of a similar endogenous rhythm of photosensitivity, postulated for the golden hamster, have been regarded as shared with an endogenous locomotor rhythm which can, of course, be directly and continuously recorded (Elliott et al., 1972). Whether or not locomotor and photosensitive rhythms are controlled by the same master clock, however, is open to some doubt (Hamner \& Enright, 1967). Follett \& Sharp (1969) measured levels of gonadotrophin-releasing 'activity' and pituitary gonadotrophins before and after alterations in the photoperiod to which Japanese quail were exposed. They were able to demonstrate some immediate endocrine correlates of the photo-inducible phase which controls gonadal development in this species.

The pineal gland may be even more closely connected with the endogenous rhythm. It influences gonadal function in rats and hamsters, perhaps through the release of serotonin and/or melatonin which can through their action on the hypothalamus, inhibit gonadotrophin release (Reiter \& Sorrentino, 1970; Fraschini, Collu \& Martini, 1971; Mess, Heizer, Tōth \& Tima, 1971). In the rat pineal there is an endogenous circadian rhythm of serotonin production which can be entrained to cyclic photoperiods, whereas levels of hydroxyindole-O-methyl transferase, necessary for the formation of melatonin from $\mathrm{N}$-acetyl serotonin, are greater during darkness than in continuous light (Axelrod, 1970). The pineal gland thus appears to have some of the characteristics required for measuring daylength on behalf of the gonads (see Wurtman, Axelrod \& Kelly, 1968). We have recently found that the inhibitory effects of $6 \mathrm{~L}: 18 \mathrm{D}$ on testis development in the vole can be overcome by pinealectomy (J. R. Clarke and G. M. Farrar, unpublished observations).

Martinet (1963) and Breed \& Clarke (1970) found that 14 or $15 \mathrm{hr}$ light daily had essentially the same effect upon sexual development in voles as longer daily photoperiods. In our earlier experiments we used a 16L:8D regimen (Clarke \& Kennedy, 1967), but the use of several different 'summer' lighting schedules 
in the present experiments may have been the cause of some of the differences in the results. Thus testes from 18L:6D males (Exp. 4) were larger than those from males in other 'summer' treatments, either 15L:9D and 3L:9D:3L:9D (Exp. 3, $P<0.001$ ) or $6 \mathrm{~L}: 30 \mathrm{D}$ (Exp. $4, P<0.01$ to 0.001 ), although the animals were similar in age. These differences could be due to variation between samples of experimental animals derived from the breeding stock. But it may also be that, above 12 to $14 \mathrm{hr}$ light daily, some photoperiods are slightly more effective than others. This could be related to some property of the postulated endogenous rhythm, such as the extent of overlap between it and the light stimulus.

The object of these experiments was to discover more about the way photoperiod affects gonadal activity. Yet none of the lighting regimens was able to cause consistently such marked inhibition or regression of testes as occurs under field conditions in the winter. In the present experiments, inhibited testes weighed on average 100 to $169 \mathrm{mg}$ and regressed ones 187 to $217 \mathrm{mg}$. In field animals the corresponding weights may be 12 and $35 \mathrm{mg}$ (Clarke \& Forsyth, 1964). In each experiment, however, there were some amongst the inhibited or regressed testes which weighed $40 \mathrm{mg}$ or less and in which seminiferous tubules were devoid of germ cells beyond the primary spermatocyte stage. This variability in response to treatments cannot be explained. Other factors presumably combine with photoperiod to cause the more radical seasonal alterations in gonads seen in wild voles. Gradual changes in photoperiod do not seem to be important for voles (Grocock, 1972) although they apparently are for sheep (Ducker, Thwaites \& Bowman, 1970). There is evidence that under real or simulated field conditions reproduction in microtine rodents is affected by population size and by nutrition (Chitty, 1952; Clarke, 1955; Smyth, 1966). Although in the laboratory ambient temperature does not appear to affect gonadal activity (Clarke \& Kennedy, 1967), it may be that in the field an interaction of photoperiod, ambient temperature and nutrition contributes to the more complete inhibition or regression of gonads in the winter. Genetic factors may also be playing a rôle in the laboratory experiments. Some animals are more susceptible than others to the effects of short photoperiods and the laboratory vole colony, in which selection for high fertility has been practised, has been a closed colony for 14 years. This may have made laboratory animals in general less sensitive to short photoperiods. It has recently been found that the $F_{1}$ generation of wild type voles reared in the laboratory appear to be more inhibited by short photoperiods than the progeny of the inbred laboratory stock (J. R. Clarke, unpublished observations).

\section{AGKNOWLEDGMENTS}

We are indebted to Professor G. E. Blackman and Professor J. H. Burnett for providing the facilities for this work, and to Mrs Judith Day for excellent technical assistance. We also wish to thank Dr R. P. Martin and Mr F. Honey, $\mathrm{Mr}$ F. Roche and Mr A. Probitts for devising and making photoperiod equipment. Part of this work was possible through a grant (AG 43/40) from the Agricultural Research Council to one of us (J.R.C.) and the other (C.A.G.) 
was the recipient of a Ministry of Agriculture, Fisheries and Food postgraduate studentship.

\section{REFERENGES}

Axelrod, J. (1970) Comparative biochemistry of the pineal gland. Am. Zoologist, 10, 259.

BaIley, U. T. J. (1959) Statistical Methods in Biology. English Universities Press, London.

BakeR, J. R. \& Ranson, R. M. (1932) Factors affecting the breeding of the field mouse (Microtus agrestis). Part 1. Light. Proc. R. Soc. B, 110, 313.

Baker, J. R. \& Ranson, R. M. (1933) Factors affecting the breeding of the field mouse (Microtus agrestis). Part 3. Locality. Proc. R. Soc. B, 113, 486.

BREed, W. G. \& Clarke, J. R. (1970) Effect of photoperiod on ovarian function in the vole, Microtus agrestis. 7. Reprod. Fert. 23, 189.

Bünning, E. (1936) Die endonome Tagesrhythmik als Grundlage der photoperiodischen Reaktion. Ber. dt. bot. Ges. 54, 590.

BUnning, E. (1963) Die physiologische Uhr. Springer, Berlin.

CHitTy, D. (1952) Mortality among voles (Microtus agrestis) at Lake Vyrnwy, Montgomeryshire in 1936-39. Phil. Trans. R. Soc. B, 236, 505.

Clarke, J. R. (1955) Influence of numbers on reproduction and survival in two experimental vole populations. Proc. $R$. Soc. B, 144, 68.

Glarke, J. R. \& Forsyth, I. A. (1964). Seasonal changes in the gonads and accessory reproductive organs of the vole (Microtus agrestis). Gen. E compar. Endocr. 4, 233.

CLARKE, J. R. \& KenNEDY, J. P. (1967) Effect of light and temperature upon gonad activity in the vole (Microtus agrestis). Gen. E compar. Endocr. 8, 474.

Decoursey, G. \& Decoursey, P. J. (1964) Adaptive aspects of activity rhythms in bats. Biol. Bull. mar. biol. Lab., Woods Hole, 126, 14.

Decoursey, P. J. (1961) Effect of light on the circadian activity rhythm of the flying squirrel, Glaucomys volans. Z. vergl. Physiol. 44, 331.

Decoursey, P. J. (1964) Function of a light response rhythm in hamsters. F. cell. comp. Physiol. 63, 189.

Ducker, M. J., Thwaites, C. J. \& Bowman, J. C. (1970) Photoperiodism in the ewe. 2. The effects of various patterns of decreasing daylength on the onset of oestrus in Clun Forest ewes. Anim. Prod. 2, 115.

Elliott, J. A., Stetson, M. H. \& Menaker, M. (1972) Regulation of testis function in golden hamsters: circadian clock measures photoperiodic time. Science, N.Y. 178, 771.

Follett, B. K. \& Sharp, P. J. (1969) Circadian rhythmicity in photoperiodically induced gonadotrophin release and gonadal growth in the quail. Nature, Lond. 223, 698.

Fraschini, F., Collu, R. \& Martini, L. (1971) Mechanism of inhibitory action of pineal principles on gonadotrophin secretion. In The Pineal Gland, pp. 259-278. Ciba Foundation Symposium. Eds. G. E. W. Wolstenholme and J. Knight. Churchill Livingstone, Edinburgh.

GRocock, C. A. (1972) The infuence of some environmental factors on the testis of the vole, with particular reference to spermatogenesis. D.Phil. thesis, Oxford University.

HamNer, W. M. (1963) Diurnal rhythm and photoperiodism in testicular recrudescence of the house finch. Science, N.Y. 142, 1294.

HAMner, W. M. \& EnRIGHT, J. T. (1967) Relationship between photoperiodism and circadian rhythms of activity in the house finch. F. exp. Biol. 46, 43.

Martinet, L. (1963) Etablissement de la spermatogenèse chez le campagnol des champs (Microtus arvalis) en fonction de la durée quotidienne d'éclairement. Annls Biol. anim. Biochim. Biophys. 3, 343.

Menaker, M. (1965) Circadian rhythms and photoperiodism in Passer domesticus. In Circadian Clocks, pp. 385-395. Ed. J. Aschoff. North-Holland Publishing Co., Amsterham.

Mess, B., Heizer, A., Töth, A. \& Trma, L. (1971) Luteinization induced by pinealectomy in the polyfollicular ovaries of rats bearing anterior hypothalamic lesions. In The Pineal Gland, pp. 229240. Ciba Foundation Symposium. Eds. G. E. W. Wolstenholme and J. Knight. Churchill Livingstone, Edinburgh.

Pittendrigh, G. S. \& Minis, D. H. (1964) The entrainment of circadian oscillations by light and their role as photoperiodic clocks. Am. Nat. 98, 261.

Reiter, R. J. \& Sorrentino, S. (1970) Reproductive effects of mammalian pineal. Am. Zoologist, 10, 247.

Sмyтн, M. (1966) Winter breeding in woodland mice, Apodemus sylvaticus, and voles, Clethrionomys glareolus and Microtus agrestis, near Oxford. 7. Anim. Ecol. 35, 471.

Wurtman, R. J., Axelrod, J. \& Kelly, D. E. (1968) The Pineal. Academic Press, New York. 